\title{
Surgery in Congenital Lung Malformations: The Evolution From Thoracotomy to Minimally Invasive Surgery, 10-year Experience in a Single Center
}

\section{Kenan Can Ceylan}

Doktor Suat Seren Gogus Hastaliklari ve Cerrahisi Egitim ve Arastirma Hastanesi

Güntuğ Batıhan ( $\square$ gbatihan@hotmail.com )

Doktor Suat Seren Gogus Hastaliklari ve Cerrahisi Egitim ve Arastirma Hastanesi https://orcid.org/0000-0001-5258-2856

Ahmet ÜçVET

Doktor Suat Seren Gogus Hastaliklari ve Cerrahisi Egitim ve Arastirma Hastanesi

Soner Gürsoy

Doktor Suat Seren Gogus Hastaliklari ve Cerrahisi Egitim ve Arastirma Hastanesi

\section{Research article}

Keywords: Congenital lung malformation, Minimally invasive surgery, VATS. Large tumors, lung cancer, thoracotomy, video-assisted thoracoscopic surgery

Posted Date: December 1st, 2020

DOI: https://doi.org/10.21203/rs.3.rs-114652/v1

License: (c) (i) This work is licensed under a Creative Commons Attribution 4.0 International License. Read Full License 


\section{Abstract}

\section{Background}

Congenital lung malformation is an umbrella term and consist of various kind of parenchymal and mediastinal pathologies. Surgical intervention is often necessary for diagnosis and treatment for these pathologies.

We aimed to review our experience in surgical treatment for congenital lung disease and present the role of minimally invasive surgery.

Methods

From January 2009 to May 2019, a total of 94 patients fitted the criteria for inclusion in this retrospective study. We investigated the clinical results obtained retrospectively.

Results

There were no significant differences between pathological subtypes in the postoperative length of hospital stay and drainage duration. There wasn't a significant difference between VATS and thoracotomy group in perioperative complications

Conclusions

Congenital lung malformations consist of a heterogeneous group of diseases and video-assisted thoracoscopic surgery should be considered as the first choice in the surgical treatment of these patients.

\section{Background}

Congenital malformation of the lung is an overarching term and consists of the bronchogenic cyst, pulmonary sequestration, congenital cystic adenoid malformation, congenital lobar emphysema, bronchial atresia, and enteric duplication cyst. It must be emphasized that there is no consensus regarding the nomenclature for these anomalies, but "congenital lung malformations" is the term that is most widely used in the literature. These malformations are usually diagnosed and managed in the newborn period, in infancy, or childhood. However, patients can also be entirely asymptomatic or present with nonspecific symptoms like cough, chest pain, or dyspnea; therefore, diagnosis may be delayed until adult age [1-3].

In literature, there are several case series of congenital lung malformations in the neonatal/early childhood period, but there isn't enough study on the results of surgical treatment in older patients [4-6].

\section{Methods}

Patient Selection 
This retrospective study was approved by the Institutional Review Board of the Dr Suat Seren Chest Diseases and Surgery Medical Practice and Research Center. We retrospectively reviewed medical records of 94 patients diagnosed with congenital lung malformation and surgically treated in our clinic between January 2009 and May 2019.

Thorax computed tomography (CT), respiratory function test and bronchoscopy were performed for all patients before surgery.

Patient demographic information, presenting symptoms, medical history, preoperative investigations, intraoperative findings, histopathology, perioperative morbidity and mortality, length of hospitalization, and drainage time were collected.

Pathological subtypes (Bronchogenic cyst, sequestration, and others) and operation procedures (VATS vs. thoracotomy) were compared in terms of postoperative length of hospital stay, drainage time, and perioperative complications. The numeric rating scale (NRS) was used for the assessment of postoperative pain, and mean scores of VATS and thoracotomy groups were compared.

A perioperative complication was defined as any complication occurring within 30 days after surgery. Prolonged air leakage was defined as air leak more than 7 days after surgery. Postoperative mortality was defined as death occurring within 30 days post-surgery.

Surgical Management

All patients were placed in the lateral decubitus position under general anesthesia with selective one-lung ventilation.

VATS was performed through two or three incisions. Camera port was located at the 7th or the 8th intercostal space on the mid-axillary. The utility incision was located at the 4th of 5th intercostal space on the mid-axillary line. The third port was opened on the posterior axillary line if needed. These described locations were varied depending on lesion location and the surgeon's personal preference.

A $10-15 \mathrm{~cm}$ posterolateral skin incision was made, and serratus anterior muscle was spared for patients who underwent thoracotomy. The thoracic cavity was entered through the 4th, 5th, or 6 th intercostal space.

The choice of the type of surgical procedure was the personal preference of the surgeon, but some patient-related factors were considered in this choice, also.

Thoracotomy was preferred in the presence of previous pulmonary infections, pleural thickening, cystic lesions larger than $5 \mathrm{~cm}$, and the inability to tolerate single lung ventilation. However, with the increased experience, VATS for congenital lung malformation has increased relative to thoracotomy. Therefore, the presence of the above-mentioned conditions should not be considered strictly contraindicated. 
Mediastinoscopy was also performed in one patient with the mediastinal cystic lesion, and total excision was achieved.

Lobectomy, pneumonectomy, wedge resection, or simple excision were performed, and intra-operative frozen section analysis was worked on the specimen if needed in case of suspicion of any malignancy.

\section{Statistical Analysis}

Data were analyzed using SPSS 22.0 (SPSS Inc., Chicago, IL, USA). Descriptive statistics for categorical variables are reported as frequency and percentage, and continuous variables are reported as mean value \pm standard deviation (SD) or median (range) as appropriate.

Categoric variables were analyzed using Pearson's chi-square test or Fisher exact test. All statistical tests were two-sided, with $p$ less than 0.05 defined as achieving statistical significance.

\section{Results}

From January 2009 to May 2019, a total of 94 patients fitted the criteria for inclusion in this retrospective study. There were 43 men and 51 women. The median age was 41 , with a range of 16 to 78 years (Table 1). 
Table 1

Patients characteristics

\begin{tabular}{|ll|}
\hline Variables & Value \\
\hline Median age(range) & $41(16-94)$ \\
\hline Sex, $\mathrm{n}(\%)$ & \\
\hline$\neg$ Male & $42(45.7)$ \\
\hline$\neg$ Female & $50(54.3)$ \\
\hline Pathology, $\mathrm{n} \%$ ) & \\
\hline$\neg$ Bronchogenic cyst & $70(76.1)$ \\
\hline$\cdot$ Mediastinal & $45(48.9)$ \\
\hline$\cdot$ Parenchimal & $25(27.1)$ \\
\hline$\neg$ Pulmonary sequestration & $14(15.2)$ \\
\hline$\bullet$ Intralobar & $11(11.9)$ \\
\hline$\cdot$ Extralobar & $3(3.3)$ \\
\hline$\neg$ Enteric duplication cyst & $4(4.4)$ \\
\hline$\neg$ Bronchial atresia & $2(2.2)$ \\
\hline$\neg$ Congenital cystic adenomatoid malformation & $2(2.2)$ \\
\hline Location of malformation, $\mathrm{n}$ (\%) & \\
\hline$\neg$ Mediastinal & $47(51.1)$ \\
\hline$\neg$ Parenchymal & $45(48.9)$ \\
\hline Surgical approach, $\mathrm{n}(\%)$ & $26(28.3)$ \\
\hline$\neg$ Thoracotomy & $1(1.1)$ \\
\hline$\neg$ VATS & \\
\hline$\neg$ Mediastinoscopy & \\
\hline
\end{tabular}

$46(\% 48.9)$ of 94 patients were asymptomatic, and the most common symptom was chest pain $(\% 16.0)$ (Table 2). 
Table 2

Presenting symptoms

\begin{tabular}{|ll|}
\hline Symptom & $\mathbf{N}(\%)$ \\
\hline Chest pain & $15(16.3)$ \\
\hline Cough & $11(12)$ \\
\hline Dyspnea & $10(10.9)$ \\
\hline Hemoptysis & $9(9.8)$ \\
\hline Fever & $2(2.2)$ \\
\hline Asymptomatic & $45(48.9)$ \\
\hline
\end{tabular}

The most common types of operation were cyst excision $(n=42, \% 44.6)$ and lobectomy $(n=30, \% 31.9)$. Intraoperative complications were seen in 2 (\%2.1) cases.

The median postoperative length of stay and drainage duration were both five days. Perioperative complications were seen in 13 (\%13.8) patients. The most seen perioperative complication was prolonged air leakage $(n=11, \% 11.7)$. There was no intraoperative or perioperative death (Table 3$)$. 
Table 3

Perioperative findings

\begin{tabular}{|ll|}
\hline Variables & Value \\
\hline Operation, $\mathbf{n}(\%)$ & \\
\hline$\neg$ Cyst excision & $42(45.6)$ \\
\hline$\neg$ Lobectomy & $29(31.5)$ \\
\hline$\neg$ Wedge resection & $12(13.0)$ \\
\hline$\neg$ Segmentectomy & $8(8.6)$ \\
\hline$\neg$ Pneumonectomy & $1(1.1)$ \\
\hline Postoperative length of hospital stays, day, median (range) & $5(2-10)$ \\
\hline Drainage duration, day, median(range) & $5(1-18)$ \\
\hline Intraoperative complication, $\mathbf{n}$ & \\
\hline$\neg$ Esophageal laceration & 2 \\
\hline$\neg$ Bronchial laceration & 1 \\
\hline$\neg$ Total (\%) & $3(3.2)$ \\
\hline Perioperative complication, $\mathbf{n}(\%)$ & \\
\hline$\neg$ Prolonged air leakage & $11(12.0)$ \\
\hline$\neg$ Hemorrhage & $1(1.1)$ \\
\hline$\neg$ Pneumonia & $1(1.1)$ \\
\hline$\neg$ Total & $13(14.2)$ \\
\hline
\end{tabular}

The most common type of lung malformation was a bronchogenic cyst $(n=71, \% 75.5)$.

There were no significant differences between pathological subtypes in the postoperative length of hospital stay and drainage duration. However, in cases of sequestration, the perioperative complication rate was significantly higher $(p=0.01)($ Table 4$)$. 
Table 4

Comparison of perioperative and postoperative results between pathological subtypes and surgical techniques.

\begin{tabular}{|c|c|c|c|}
\hline Pathological subtypes & $\begin{array}{l}\text { Postoperative length } \\
\text { of hospital stays, day, } \\
\text { median } \\
(p=0.843)\end{array}$ & $\begin{array}{l}\text { Drainage } \\
\text { duration, day, } \\
\text { median } \\
(p=0.459)\end{array}$ & $\begin{array}{l}\text { Perioperative } \\
\text { complication, } n \\
(\%)(p=0.022)\end{array}$ \\
\hline Bronchogenic cyst $(n=70)$ & 5.59 & 5.07 & $5(7.2)$ \\
\hline Sequestration $(n=14)$ & 6.00 & 5.54 & $5(38.5)$ \\
\hline $\begin{array}{l}\text { Others }(n=8)(\text { Enteric duplication } \\
\text { cyst, bronchial atresia, congenital } \\
\text { cystic adenomatoid malformation) }\end{array}$ & 6.30 & 5.40 & $2(20)$ \\
\hline Operation type & $\begin{array}{l}\text { Postoperative length } \\
\text { of hospital stays, day, } \\
\text { median }(p=0.706)\end{array}$ & $\begin{array}{l}\text { Drainage } \\
\text { duration, day, } \\
\text { median( }(\mathrm{p}= \\
0.717)\end{array}$ & $\begin{array}{l}\text { Perioperative } \\
\text { complication, } \mathrm{n} \\
(\%)(\mathrm{p}=0.343)\end{array}$ \\
\hline VATS & 6.04 & 5.38 & $5(19.2)$ \\
\hline Thoracotomy & 5.74 & 5.12 & $7(12.3)$ \\
\hline Postoperative period (day) & $\begin{array}{l}\text { Pain score in VATS } \\
\text { group (mean } \pm S D)\end{array}$ & $\begin{array}{l}\text { Pain score in } \\
\text { Thoracotomy } \\
\text { group (mean } \pm \\
\text { SD) }\end{array}$ & $P$ value \\
\hline 1 & $3.23 \pm 0.84$ & $3.86 \pm 0.92$ & 0.045 \\
\hline 2 & $2.47 \pm 0.80$ & $3.15 \pm 1.15$ & 0.025 \\
\hline 3 & $2.45 \pm 0.85$ & $3.25 \pm 1.25$ & 0.025 \\
\hline
\end{tabular}

The mean postoperative length of hospital stay and drainage duration was longer in the VATS group, but this data wasn't statistically significant $(p=0.706 / p=0.717)$. There wasn't a significant difference between VATS and thoracotomy group in perioperative complications (Table 4).

The mean pain scores were lower in the VATS group in the first three days of the postoperative period, and this difference was statistically significant (Table 4).

\section{Discussion}

The spectrum of congenital lung malformations includes bronchogenic cyst, sequestration, congenital cystic adenomatoid malformation (CTM), bronchial atresia, enteric, and duplication cysts.

Although CTM is usually detected antenatally, the diagnosis may be missed until later in life, especially in asymptomatic cases. 
The respiratory system begins the develop at about the 4th week of gestation from the ventral wall of the primitive foregut. This process continues until early childhood and consists of five stages: Embryonic, pseudoglandular, canalicular, saccular, and alveolar. Most of the congenital lung malformations develop in the pseudoglandular phase, which is completed at the end of the 16 th week $[7,8]$.

Despite some similarities, congenital lung malformations are a heterogeneous group and cover a wide range of disorders. Therefore, we discussed the types of malformations in our case series under separate headings.

\section{Bronchogenic cysts}

A bronchogenic cyst is the most common congenital malformation of the mediastinum. They usually present as small, solitary cysts located in the mediastinum or pulmonary parenchyma. In imaging techniques, the density/intensity of the bronchogenic cysts may vary according to the cyst content, and they can mimic other mediastinal or parenchymal pathologies. Therefore, the bronchogenic cyst should be considered in the differential diagnosis of mediastinal and parenchymal lesions. Peripheral bronchogenic cysts are usually seen as multiloculated, thin-walled parenchymal lesions. They tend to have bronchial communication, and this situation can cause recurrent pneumonia, infection of the cyst, fever, sepsis, respiratory distress, or even severe hemoptysis. It was also reported that malignancy could develop on the wall of long-standing bronchogenic cysts. Therefore, the consensus in the treatment of this congenital malformation is complete surgical resection, even if the patient is asymptomatic [9-13].

In our experience, we detected two cases of malignant tumors arising from the bronchogenic cyst. One of them was mucoepidermoid carcinoma, and the other one was atypical carcinoid tumors of the lung. In both cases, bronchogenic cysts were located in pulmonary parenchyma and required anatomic lung resection. We also detected bronchogenic cyst incidentally in two cases of non-small cell lung cancer intraoperatively. In these two cases, the tumor was centrally located and accompanied by multiple mediastinal lymph nodes. The bronchogenic cyst was also located in the mediastinum and resected with other mediastinal lymph nodes. This is important for confusing the surgeon by creating the impression of a lymph node invading the bronchus. Therefore, in such cases, the result of the frozen section should be waited before beginning the anatomic resection.

We retrospectively analyzed 71 cases of a bronchogenic cyst in our series. Bronchogenic cysts were located in the mediastinum in 45 and pulmonary parenchyma in 26 out of 71 cases (Figure 1). VATS procedure was performed in 16 out of 71 patients. The intraoperative complication was seen in two cases. In the first case, esophageal and bronchial laceration were seen together. In the other case, only esophagus perforation was seen. In these cases, the wall of the bronchogenic cyst strongly adhered to the bronchus and esophagus. Both lacerations occurred while dissection of the cyst wall from surrounding structures. These complications were detected intraoperatively and repaired without any problem. 
Sometimes, bronchogenic cysts can reach large sizes and become perforated. This situation was observed in one of our patients (Figure 2). In such cases, surgery should be performed immediately.

\section{Sequestration}

Pulmonary sequestration is a rare malformation characterized by non-functional parenchymal mass, which receives arterial supply from aberrant systemic arteries. Pulmonary sequestration is divided into intralobar sequestration, which is located in normal pulmonary parenchyma without its pleural covering, and extralobar sequestration, which is separated from normal lung tissue by its pleural covering. Because of its distinctive arterial supply, this congenital anomaly may also be considered as a vascular malformation. Arterial supply of the pulmonary sequestration is usually from the descending thoracic or abdominal aorta, and venous drainage is usually toward the pulmonary veins (Figure 3 ).

Patients can remain asymptomatic and be diagnosed incidentally or presented with dyspnea, cyanosis, recurrent pulmonary infection, and hemoptysis. Malignant transformation may also be seen in these patients. Therefore, surgical resection is the main treatment modality for pulmonary sequestrations, even for an asymptomatic patient [14-16].

In our series, we reviewed 15 patients with pulmonary sequestration. 11 of 14 patients had intralobar sequestration, and 4 had extralobar sequestration. VATS procedure was performed successfully in 6 out of 15 patients without any intraoperative complications. We also performed pneumonectomy in one case with synchronous extralobar pulmonary sequestration and centrally located lung cancer.

Preoperative evaluation of the arterial supply of pulmonary sequestration is essential for reducing the risk of intraoperative vascular injury $[17,18]$. Therefore, we used 3D multidetector CT angiography in all cases of pulmonary sequestration preoperatively. Thorax CT images of some of our cases are seen in Figure 4 .

Compared to other congenital lung malformations, patients with sequestration had a higher rate of perioperative complications (\%40.0), especially prolonged air leakage, and this data was statistically significant $(p=0.01)$. This result can be explained by the need for anatomic lung resection instead of simple cystectomy in patients with pulmonary sequestration.

Congenital Cystic adenomatoid malformation (CCAM)

CCAM is a rare malformation characterized by cystic areas in the lung parenchyma and adenomatous overgrowth of the terminal bronchioles. Most of the cases are diagnosed prenatal or postnatally, and approximately $40 \%$ of the cases present with hydrops fetalis. In the presence of a small localized lesion, patients can remain asymptomatic for a long time and can be detected incidentally in later years, but most of the patients present with unresolving pulmonary infiltration, recurrent pneumonia, pneumothorax, or pleural effusion $[19,20]$.

Surgical resection is the main treatment in patients with CCAM. The size and extent of the lesion determine the extent of surgical resection. 
In our series, we surgically treated 2 cases of CCAM. One of these two patients had dyspnea, and the other had mild hemoptysis. Left upper and left lower lobectomy was needed to complete resection (Figure $5)$.

\section{Bronchial Atresia}

Bronchial atresia is a rare congenital malformation characterized by focal interruption of lobar, segmental, or subsegmental bronchus.

In the embryological process, bronchial buds occur at the end of the 4th gestational week and continue to branch between 7th-16th weeks. Defect in vascularization can impact the branching of the bronchial buds and can cause interruption of a lobar or segmental bronchus. This results in mucus impaction and distension of the corresponding pulmonary parenchyma. Like many other malformations, bronchial atresia is most often diagnosed in the neonatal period or the young child. Surgical resection must be considered to make a diagnosis and prevent possible complications, even in asymptomatic patients $[21,22]$.

In our series, bronchial atresia was detected in 2 cases. In these cases, atresia was containing left upper lobe anterior, and apicoposterior segment bronchus and pulmonary parenchyma distal to these bronchi were hyperinflated. Videothoracoscopic left upper lobe tri-segmentectomy was performed without any complication in both cases.

Enteric duplication cyst

Enteric duplication cyst is a rare congenital malformation originate from any part of the gastrointestinal tract. It was reported that approximately 20 percent of cases are located in the mediastinum, and most of them are detected in childhood. Symptoms depend on the size and location of the cyst, but dyspnea, stridor, cough, and chest pain may be present [23]. In our series, we detected 4 cases of mediastinal enteric duplication cysts, and surgical excision was performed.

Today VATS procedure is widely used in the diagnosis and treatment of different kinds of pulmonary, mediastinal, and pleural pathologies, and its indication is extending day by day.

In several studies, VATS was compared with thoracotomy, and it has been described as a safe and feasible technique for the treatment of congenital lung diseases (Table 5).

In addition to the described benefits, VATS also allows excellent exposure of the entire hemithorax and allows the entire surgical team to follow every stage of the operation, but this procedure should be encouraged only for experienced surgeons.

With the increasing experience in our center, VATS has become the increasingly preferred method of surgical approach in patients with congenital lung malformation. 
In our series, we performed a VATS procedure in 26 out of 94 patients. The intraoperative complication was seen in one case (esophagus laceration), and perioperative complication was seen in 5 cases (\%19.2).

There weren't any statistically significant differences between VATS and thoracotomy groups in terms of perioperative complications, median postoperative length of hospital stays, and median drainage duration but mean postoperative pain score was significantly lower in the VATS group.

This study had some limitations. First, it is a retrospective study, and patient selection bias existed. Second, congenital lung malformations consist of a heterogeneous group of patients; therefore, it is difficult to make comprehensive inferences. Third, the criteria for selecting VATS were not defined clearly, and we analyzed only a small number of patients at a single institution, a further large-scale prospective study will be necessary to investigate the efficacy and feasibility of VATS.

\section{Conclusions}

In conclusion, congenital lung malformation is an umbrella term and consist of various kind of parenchymal and mediastinal pathologies. To prevent future complications, surgery is always almost needed, even in asymptomatic patients.

In this study, there are no significant differences between VATS and thoracotomy groups in terms of intraoperative and perioperative complication rates, drainage, and hospitalization durations, but the advantage of VATS in postoperative pain control was also seen in our study. Because of possible and described benefits of minimally invasive surgical techniques, VATS should be considered as the first choice in the surgical treatment of patients with congenital lung malformations.

\section{Declarations}

\section{Ethics approval and consent to participate}

This retrospective study was approved by the Institutional Review Board (Reg. no. 49109414-604.02).

\section{Consent for publication}

The authors declare that written consent was obtained from study participants.

\section{Availability of data and materials}

Not applicable.

\section{Competing interests}

The authors declare that they have no competing interests. 


\section{Funding}

The authors declare that no funding was received for present study.

\section{Authors' contributions}

$\mathrm{KCC}$ was a major contributor in data curation and writing the manuscript. GB was a major contributor in review and editing the manuscript. AU and SG were a major contribution in editing and supervision. GB and KCC performed the statistical analyses.

\section{Acknowledgements}

Not applicable.

\section{References}

1- Shanmugam, G. (2005). Adult congenital lung disease. European Journal of Cardio-Thoracic Surgery, 28(3), 483-489.

2- Annunziata F, Bush A, Borgia F, Raimondi F, Montella S, Poeta M, et al. Congenital Lung Malformations: Unresolved Issues and Unanswered Questions. Frontiers in Pediatrics, 7.

3- Patz Jr EF, Muller NL, Swensen SJ, Dodd LG. Congenital cystic adenomatoid malformation in adults: CT findings. J Comput Assist Tomogr 1995;19(3):361-4.

4- Coran AG, Drongowski R. Congenital cystic disease of the tracheobronchial tree in infants and children. Experience with 44 consecutive cases. Arch Surg. 1994;129:521-7.

5- Rogers LF, Osmer JC. Bronchogenic cyst. A review of 46 cases. Am J Roentgenol Radium Ther Nucl Med. 1964;91:273-90.

6- Thakral CL, Maji DC, Sajwani MJ. Congenital lobar emphysema: Experience with 21 cases. Pediatr Surg Int. 2001;17:88-91.

7- Schittny JC. Development of the lung. Cell Tissue Res. 2017 Mar;367(3):427-444.

8- Lee EY, Dorkin H, Vargas SO. Congenital pulmonary malformations in pediatric patients: review and update on etiology, classification, and imaging findings, Radiol Clin N. Am. 49 (5) (2011) 921-948.

9- St-Georges R, Deslauriers J, Duranceau A, Vaillancourt R, Deschamps C, Beauchamp G, et al. (1991). Clinical spectrum of bronchogenic cysts of the mediastinum and lung in the adult. The Annals of Thoracic Surgery, 52(1), 6-13.

10-Lardinois D, Gugger M, Ris HB. Bronchogenic cyst of the left lower lobe associated with severe hemoptysis. Eur J Cardiothorac Surg 1999;16(3): 382-3. 
11- Kostopoulos G, Efstathiou A, Skordalaki A, Fessatidis I. Bronchogenic cyst infected by Salmonella enteritidis followed gastroenteritis. Eur J Cardiothorac Surg 2002;21(5):935-7.

12- Yoon YC, Lee KS, Kim TS, Kim J, Shim YM, Han J. Intrapulmonary bronchogenic cyst: CT and pathologic findings in five adult patients. Am J Roentgenol 2002;179(1):167-70.

13- Tireli GA, Ozbey H, Temiz A, Salman T, Celik A. Bronchogenic cysts: a rare congenital cystic malformation of the lung. Surgery Today. 2004;34(7):573-576.

14- Savic B, Birtel FJ, Tholen W, Funke HD, Knoche R. Lung sequestration: report of seven cases and review of 540 published cases. Thorax 1979;34: 96-101.

15- Lin CH, Chuang CY, Hsia JY, Lee MC, Shai SE, Yang SS, et al. Pulmonary sequestration-differences in diagnosis and treatment in a single institution. J Chin Med Assoc 2013;76:385-9.

16- Liu HS, Li SQ, Qin YZ, Zhang ZY, Ren H. Surgical treatment of intralobar pulmonary sequestration. Chin Med Sci J 2010;25:53-6.

17- Abbey P, Das CJ, Pangtey GS, Seith A, Dutta R, Kumar A. Imaging in bronchopulmonary sequestration. J Med Imaging Radiat Oncol 2009; 53:22-31.

18- Gezer S, Tastepe I, Sirmali M, Findik G, Türüt H, Kaya S et al. Pulmonary sequestration: a singleinstitutional series composed of 27 cases. Journal of Thoracic and Cardiovascular Surgery. 2007;133(4):955-959.

19- Marshall KW, Blane CE, Teitelbaum DH, van Leeuwen K. Congenital cystic adenomatoid malformation: impact of prenatal diagnosis and changing strategies in the treatment of the asymptomatic patient. AJR Am J Roentgenol 2000;175: 1551-4.

20-Stocker JT, Madewell JE, Drake RM. Congenital cystic adenomatoid malformation of the lung. Classification and morphologic spectrum. Hum Pathol. 1977;8:155-171.

21- Mordant P, De Dominicis F, Berna P, Riquet M. Tracheobronchial and pulmonary parenchymatous congenital abnormalities requiring surgical treatment in adults. Rev Pneumol Clin 2012;68:110-6. 10.1016/j.pneumo.2012.01.008

22- Traibi A, Seguin-Givelet A, Grigoroiu M, Brian E, Gossot D. Congenital bronchial atresia in adults: thoracoscopic resection. J Vis Surg. 2017;3:174. Published 2017 Nov 30.

23- Liu R, Adler DG. Duplication cysts: Diagnosis, management, and the role of endoscopic ultrasound. Endosc Ultrasound. 2014;3(3):152-160.

24- Jung HS, Kim DK, Lee GD, Sim HJ, Choi SH, Kim HR, et al. Video-assisted thoracic surgery for bronchogenic cysts: is this the surgical approach of choice? Interactive CardioVascular and Thoracic 
Surgery 19 (2014) 824-829.

25- Guo C, Mei J, Liu C, Deng S, Pu Q, Lin F, et al. Video-assisted thoracic surgery compared with posterolateral thoracotomy for mediastinal bronchogenic cysts in adult patients. J Thorac Dis. 2016;8(9):2504-2511.

26- Wang X, Chen K, Li Y, Yang F, Zhao H, Wang J. The Video-Assisted Thoracic Surgery for Mediastinal Bronchogenic Cysts: A Single-Center Experience. World J Surg. 2018 Nov;42(11):3638-3645.

27- Liu C, Pu Q, Ma L, Mei J, Xiao Z, Liao H, et al. Video-assisted thoracic surgery for pulmonary sequestration compared with posterolateral thoracotomy. J Thorac Cardiovasc Surg. 2013 Sep;146(3):557-61.

28-Sun X, Xiao Y. Pulmonary sequestration in adult patients: a retrospective study. European Journal of Cardio-Thoracic Surgery (2014) 1-4.

29- Vu LT, Farmer DL, Nobuhara KK, Miniati D, Lee H. Thoracoscopic versus open resection for congenital cystic adenomatoid malformations of the lung. J Pediatr Surg. 2008 Jan;43(1):35-9.

30- Makhija Z, Moir CR, Allen MS, Cassivi SD, Deschamps C, Nichols FC, et al. Surgical management of congenital cystic lung malformations in older patients. Ann Thorac Surg. 2011 May;91(5):1568-73.

\section{Tables}

Table 1. Patients characteristics 


\begin{tabular}{|c|c|}
\hline Variables & Value \\
\hline Median age(range) & 41(16-94) \\
\hline \multicolumn{2}{|l|}{ Sex, n (\%) } \\
\hline$\varnothing$ Male & $42(45.7)$ \\
\hline$\varnothing$ Female & $50(54.3)$ \\
\hline \multicolumn{2}{|l|}{ Pathology, n (\%) } \\
\hline$\varnothing$ Bronchogenic cyst & $70(76.1)$ \\
\hline . $\quad$ Mediastinal & $45(48.9)$ \\
\hline · $\quad$ Parenchimal & $25(27.1)$ \\
\hline$\varnothing$ Pulmonary sequestration & 14(15.2) \\
\hline . Intralobar & 11(11.9) \\
\hline . Extralobar & $3(3.3)$ \\
\hline$\varnothing$ Enteric duplication cyst & $4(4.4)$ \\
\hline$\varnothing$ Bronchial atresia & $2(2.2)$ \\
\hline$\varnothing$ Congenital cystic adenomatoid malformation & $2(2.2)$ \\
\hline \multicolumn{2}{|l|}{ Location of malformation, $\mathrm{n}(\%)$} \\
\hline$\varnothing$ Mediastinal & $47(51.1)$ \\
\hline$\varnothing$ Parenchymal & $45(48.9)$ \\
\hline \multicolumn{2}{|l|}{ Surgical approach, $n(\%)$} \\
\hline$\varnothing$ Thoracotomy & $65(70.7)$ \\
\hline$\varnothing$ VATS & $26(28.3)$ \\
\hline$\emptyset$ Mediastinoscopy & $1(1.1)$ \\
\hline
\end{tabular}

Table 2. Presenting symptoms 


\begin{tabular}{|lc|}
\hline Symptom & $\mathbf{N}(\%)$ \\
\hline Chest pain & $15(16.3)$ \\
\hline Cough & $11(12)$ \\
\hline Dyspnea & $10(10.9)$ \\
\hline Hemoptysis & $9(9.8)$ \\
\hline Fever & $2(2.2)$ \\
\hline Asymptomatic & $45(48.9)$ \\
\hline
\end{tabular}

Table 3. Perioperative findings 


\begin{tabular}{|ll|}
\hline Variables & Value \\
\hline Operation, $\mathbf{n}(\%)$ & \\
\hline$\varnothing$ Cyst excision & $42(45.6)$ \\
\hline$\varnothing$ Lobectomy & $29(31.5)$ \\
\hline$\varnothing$ Wedge resection & $12(13.0)$ \\
\hline$\varnothing$ Segmentectomy & $8(8.6)$ \\
\hline$\varnothing$ Pneumonectomy & $1(1.1)$ \\
\hline Postoperative length of hospital stays, day, median (range) & $5(2-10)$ \\
\hline Drainage duration, day, median(range) & $5(1-18)$ \\
\hline Intraoperative complication, $\mathbf{n}$ & \\
\hline$\varnothing$ Esophageal laceration & 2 \\
\hline$\varnothing$ Bronchial laceration & 1 \\
\hline$\varnothing$ Total (\%) & $3(3.2)$ \\
\hline Perioperative complication, $\mathbf{n}(\%)$ & $1(1.1)$ \\
\hline$\varnothing$ Prolonged air leakage & $13(14.2)$ \\
\hline$\varnothing$ Hemorrhage & $1(12.0)$ \\
\hline$\varnothing$ Pneumonia & \\
\hline$\varnothing$ Total & \\
\hline
\end{tabular}

Table 4. Comparison of perioperative and postoperative results between pathological subtypes and surgical techniques. 


\begin{tabular}{|c|c|c|c|}
\hline Pathological subtypes & $\begin{array}{l}\text { Postoperative length } \\
\text { of hospital stays, day, } \\
\text { median } \\
(p=0.843)\end{array}$ & $\begin{array}{l}\text { Drainage } \\
\text { duration, day, } \\
\text { median } \\
(p=0.459)\end{array}$ & $\begin{array}{l}\text { Perioperative } \\
\text { complication, } \\
\text { n }(\%) \\
(p=0.022)\end{array}$ \\
\hline Bronchogenic cyst $(n=70)$ & 5.59 & 5.07 & $5(7.2)$ \\
\hline Sequestration $(n=14)$ & 6.00 & 5.54 & $5(38.5)$ \\
\hline $\begin{array}{l}\text { Others }(n=8) \text { (Enteric duplication cyst, } \\
\text { bronchial atresia, congenital cystic } \\
\text { adenomatoid malformation) }\end{array}$ & 6.30 & 5.40 & $2(20)$ \\
\hline Operation type & $\begin{array}{l}\text { Postoperative length } \\
\text { of hospital stays, day, } \\
\text { median }(p=0.706)\end{array}$ & $\begin{array}{l}\text { Drainage } \\
\text { duration, day, } \\
\text { median }(p=0.717)\end{array}$ & $\begin{array}{l}\text { Perioperative } \\
\text { complication, } \\
\text { n }(\%) \\
(p=0.343)\end{array}$ \\
\hline VATS & 6.04 & 5.38 & $5(19.2)$ \\
\hline Thoracotomy & 5.74 & 5.12 & $7(12.3)$ \\
\hline Postoperative period (day) & $\begin{array}{l}\text { Pain score in VATS } \\
\text { group (mean } \pm S D \text { ) }\end{array}$ & $\begin{array}{l}\text { Pain score in } \\
\text { Thoracotomy } \\
\text { group } \\
\text { (mean } \pm S D \text { ) }\end{array}$ & $P$ value \\
\hline 1 & $3.23 \pm 0.84$ & $3.86 \pm 0.92$ & 0.045 \\
\hline 2 & $2.47 \pm 0.80$ & $3.15 \pm 1.15$ & 0.025 \\
\hline 3 & $2.45 \pm 0.85$ & $3.25 \pm 1.25$ & 0.025 \\
\hline
\end{tabular}

Table 5. Literature review 


\begin{tabular}{|c|c|c|c|c|}
\hline Author & Year & $\begin{array}{l}\text { Number of } \\
\text { Patients }\end{array}$ & Patient group & Key results \\
\hline $\begin{array}{l}\text { Jung } \\
\text { HS. et } \\
\text { al. [24] }\end{array}$ & 2014 & $\begin{array}{l}113 \text { (All } \\
\text { patients } \\
\text { underwent } \\
\text { VATS; } 4 \\
\text { patients were } \\
\text { converted to } \\
\text { open } \\
\text { thoracotomy) }\end{array}$ & $\begin{array}{l}\text { Bronchogenic } \\
\text { cyst }\end{array}$ & $\begin{array}{l}\text { The median operation time was } 96.8 \text { min } \\
\text { (range, 15-320 min). There were no operative } \\
\text { mortalities or major postoperative } \\
\text { complications. VATS excision of } \\
\text { bronchogenic cysts described as safe and } \\
\text { feasible. }\end{array}$ \\
\hline $\begin{array}{l}\text { Guo et } \\
\text { al. [25] }\end{array}$ & 2016 & $\begin{array}{l}99(\mathrm{~V}: 65, \\
\mathrm{T}: 34)\end{array}$ & $\begin{array}{l}\text { Bronchogenic } \\
\text { cyst }\end{array}$ & $\begin{array}{l}\text { The VATS group had shorter operative time } \\
(108.77 \pm 47.81 \text { vs. } 144.62 \pm 55.16, P=0.001) \text {, } \\
\text { shorter hospital stay and drainage time } \\
(4.94 \pm 2.01 \text { vs. } 8.64 \pm 5.52 \text { days, } P=0.001 \\
2.52 \pm 1.29 \text { vs. } 3.71 \pm 1.55 \text { days, } P<0.001 \\
\text { respectively). }\end{array}$ \\
\hline $\begin{array}{l}\text { Wang } \\
\text { et al. } \\
\text { [26] }\end{array}$ & 2018 & $\begin{array}{l}119 \text { (All } \\
\text { patients } \\
\text { underwent } \\
\text { VATS; } 1 \\
\text { patient was } \\
\text { converted to } \\
\text { open } \\
\text { thoracotomy) }\end{array}$ & $\begin{array}{l}\text { Bronchogenic } \\
\text { cyst }\end{array}$ & $\begin{array}{l}\text { Mean operative time was } 103.8 \pm 41.6 \mathrm{~min} \\
(40-360 \mathrm{~min}) \text {. The intraoperative } \\
\text { complication rate was } 3.4 \% \text {. VATS was } \\
\text { described as safe and reliable for the } \\
\text { management of MBCs }\end{array}$ \\
\hline $\begin{array}{l}\text { Liu et } \\
\text { al. [27] }\end{array}$ & 2013 & $\begin{array}{l}42(\mathrm{~V}: 18, \\
\mathrm{T}: 24)\end{array}$ & $\begin{array}{l}\text { Pulmonary } \\
\text { sequestration }\end{array}$ & $\begin{array}{l}\text { No significant differences were found } \\
\text { between VATS and thoracotomy group in } \\
\text { terms of the duration of operation, blood loss, } \\
\text { amount of chest drainage, duration of chest } \\
\text { drainage, length of postoperative hospital } \\
\text { stay, and complications. }\end{array}$ \\
\hline $\begin{array}{l}\text { Sun X. } \\
\text { et al. } \\
\text { [28] }\end{array}$ & 2014 & $69(\mathrm{~V}: 9, \mathrm{~T}: 55)$ & $\begin{array}{l}\text { Pulmonary } \\
\text { sequestration }\end{array}$ & $\begin{array}{l}\text { Length of postoperative hospital stay was } \\
\text { shorter in VATS group both for ILS and ELS } \\
\text { patients. (6.6 } \pm 1.5 \text { vs } 9.1 \pm 3.2 \text { days, } P= \\
0.001)(7.2 \pm 0.84 \text { vs } 9.2 \pm 3.2 \text { days, } p=0.002\end{array}$ \\
\hline $\begin{array}{l}\text { Vu et al. } \\
\text { [29] }\end{array}$ & 2008 & $\begin{array}{l}36(\mathrm{~V}: 12 \\
\mathrm{T}: 24)\end{array}$ & CCAM & $\begin{array}{l}\text { Patients in the VATS group had significantly } \\
\text { longer operative time (mean difference of } 61.3 \\
\text { minutes; } 95 \% \text { confidence interval [CI], 30.5- } \\
92.1 \text { ) but shorter postoperative hospital stay } \\
\text { (mean difference of } 5.7 \text { days; } 95 \% \mathrm{Cl}, 0.9- \\
\text { 10.4) and duration of tube thoracostomy } \\
\text { (mean difference of } 2.6 \text { days; } 95 \% \mathrm{Cl}, 0.7-4.5 \text { ) }\end{array}$ \\
\hline $\begin{array}{l}\text { Makhija } \\
\text { Z. el al. } \\
\text { [30] }\end{array}$ & 2011 & $\begin{array}{l}102(\mathrm{~V}: 70, \\
\mathrm{T}: 21 \\
\text { Others:11\%) }\end{array}$ & $\begin{array}{l}\text { Congenital } \\
\text { cystic lung } \\
\text { malformations }\end{array}$ & $\begin{array}{l}\text { There isn't any comparison between VATS and } \\
\text { thoracotomy in this study, but it was reported } \\
\text { that pneumonia and bronchogenic cysts } \\
\text { predictors of the need for a more extensive } \\
\text { pulmonary resection. }\end{array}$ \\
\hline
\end{tabular}




$\begin{array}{llll}\begin{array}{l}\text { Current } \\ \text { study }\end{array} & 92(\mathrm{~V}: 26, & \begin{array}{l}\text { Congenital } \\ \text { lung } \\ \text { malformations }\end{array} & \begin{array}{l}\text { No significant differences between VATS and } \\ \text { thoracotomy group in terms of mean } \\ \text { postoperative length of hospital stay, drainage } \\ \text { duration and perioperative complications } \\ \end{array} \\ & \begin{array}{l}\text { (6.04 vs } 5.74 \text { days, } p=0.706)(5.38 \text { vs } 5.12 \\ \text { days, } p=0.717)(\% 19.2 \text { vs } \% 12.3, p=0.343)\end{array}\end{array}$

V: VATS, T: Thoracotomy, M: Mediastinoscopy, MBC: Mediastinal bronchogenic cyst, CCAM: Congenital cystic adenoid malformation ILS: Intralober sequestration, ELC: Extralober sequestration

*Sternotomy: 5, Mediastinoscopy: 4, laparoscopy: 1 and cervical: 1

\section{Figures}




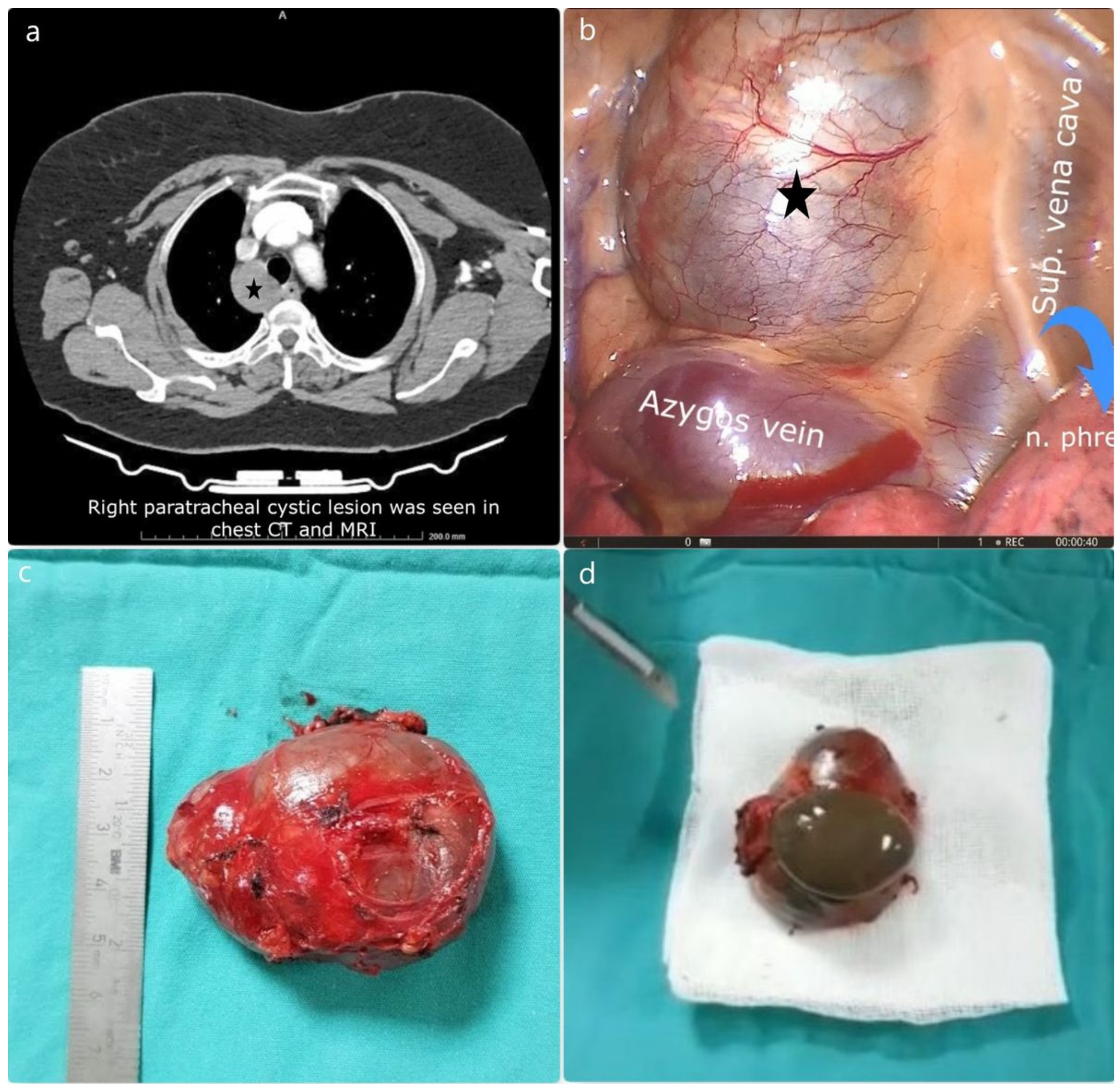

Figure 1

The right mediastinal cystic lesion was observed in the thorax CT (Figure 1a). VATS resection of the mediastinal bronchogenic cyst (Asterisk) was performed. Brown mucoid content was observed in the macroscopy of the resection material (Figure 1d). 


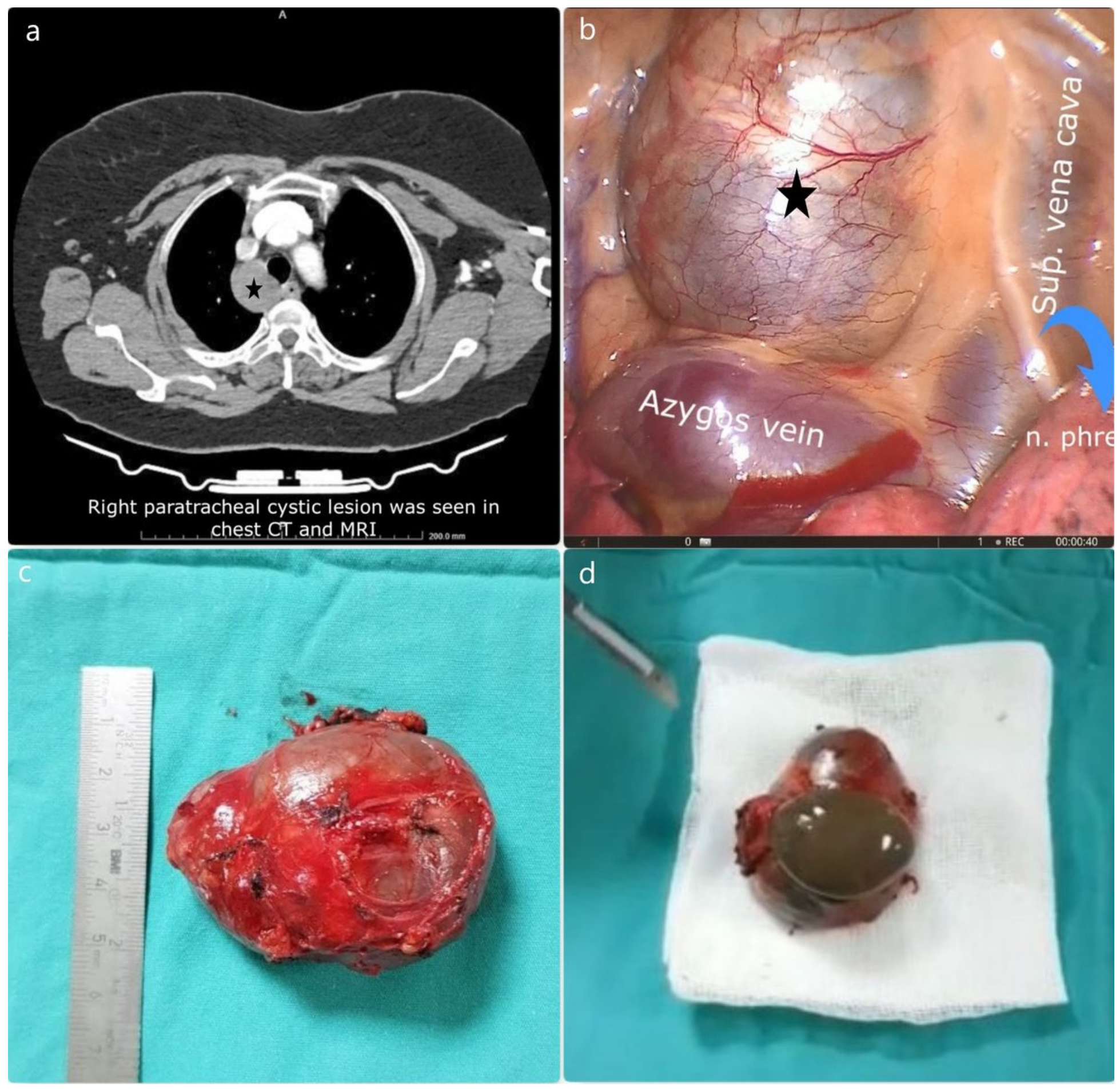

Figure 1

The right mediastinal cystic lesion was observed in the thorax CT (Figure 1a). VATS resection of the mediastinal bronchogenic cyst (Asterisk) was performed. Brown mucoid content was observed in the macroscopy of the resection material (Figure 1d). 

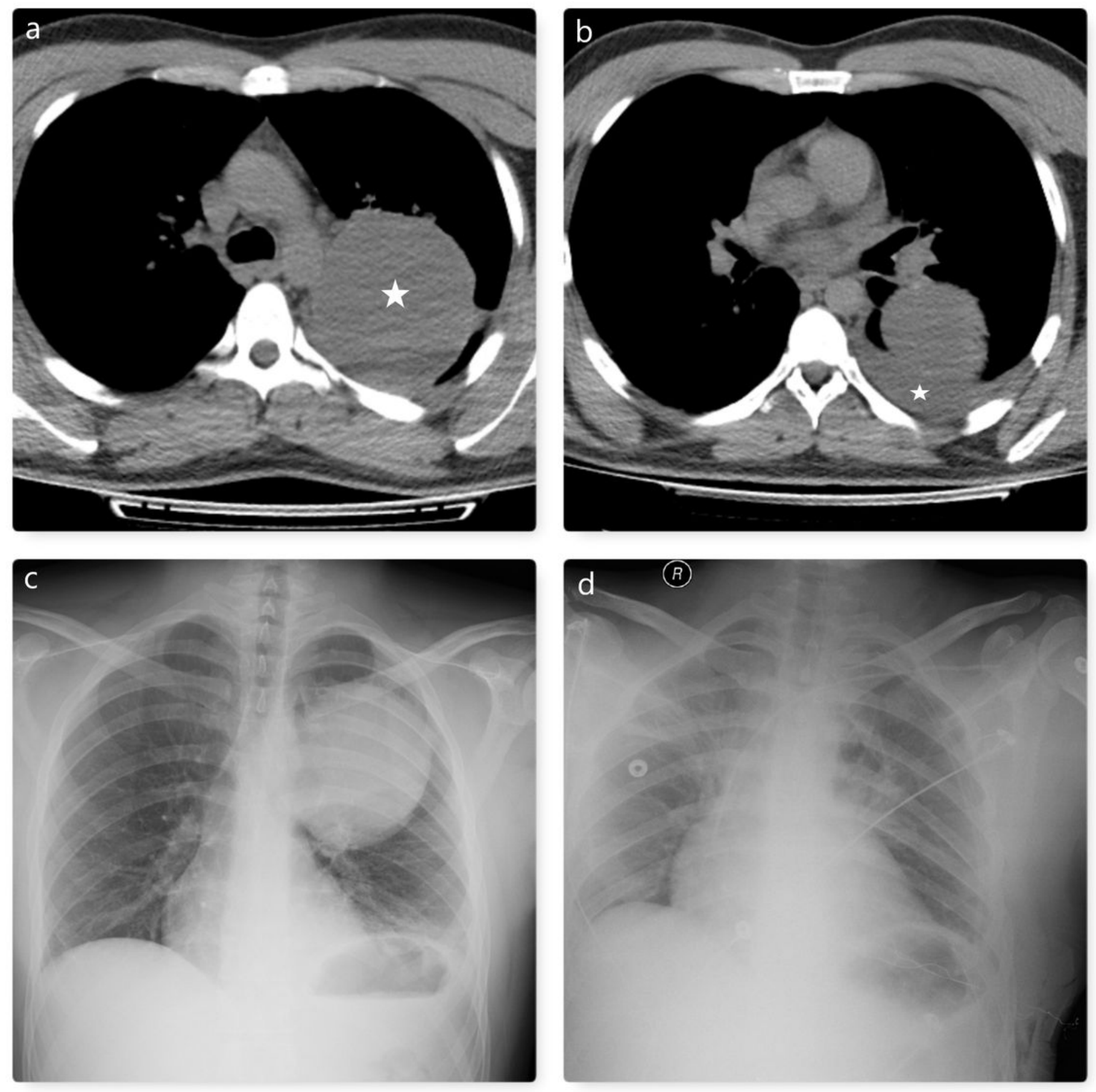

Figure 2

a. The left-sided giant bronchogenic cyst is seen in the thorax CT (Asterisk). b. This image shows pleural effusion accompanying bronchogenic cyst (Asterisk). Such effusions may occur due to atelectasis and disruption of lymphatic drainage, or they may be indicative of perforation in the cyst. In this case, perforation was detected intraoperatively. $\mathrm{c}$ and $2 \mathrm{~d}$ indicate preoperative and postoperative chest radiograms. 

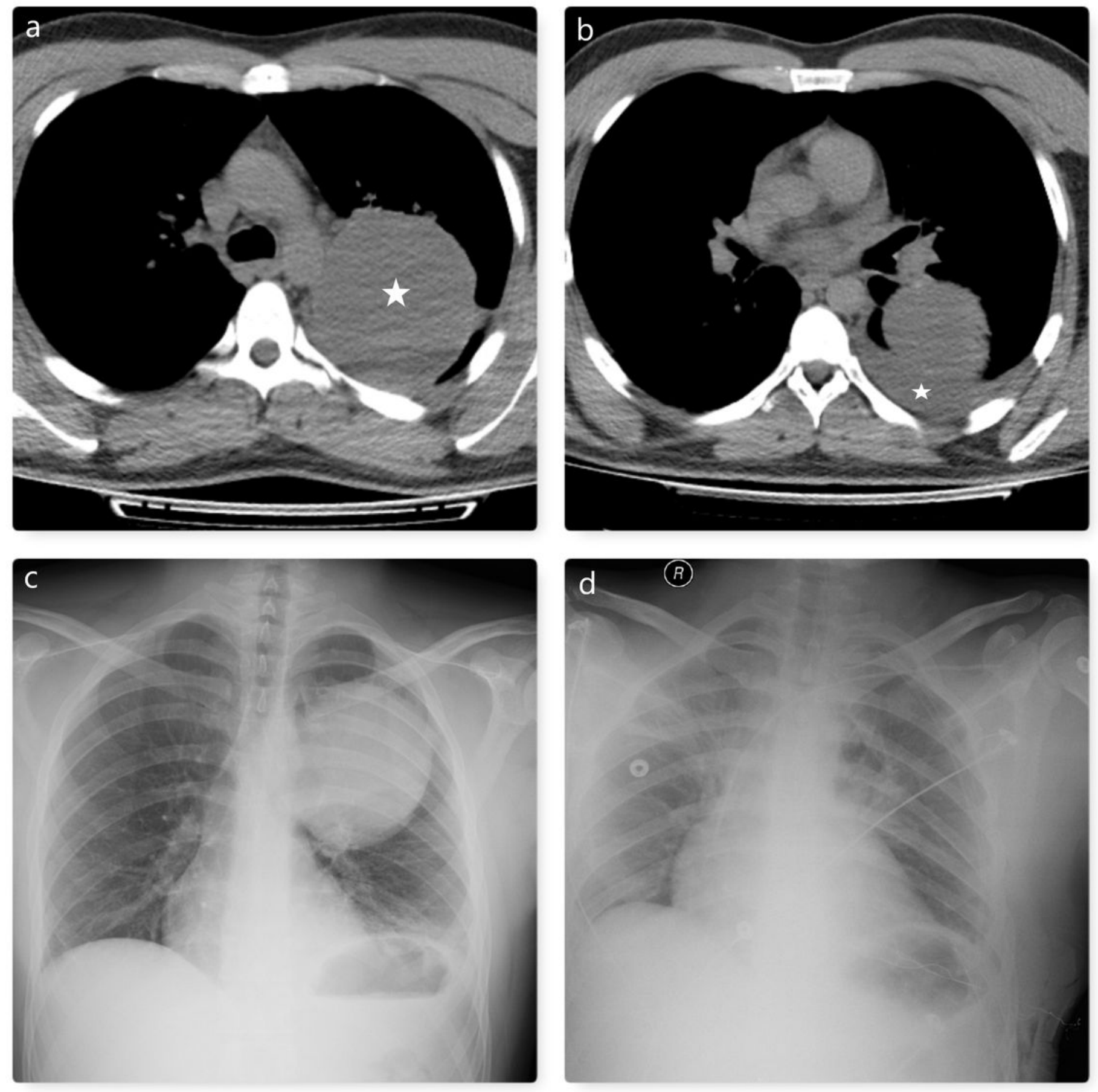

Figure 2

a. The left-sided giant bronchogenic cyst is seen in the thorax CT (Asterisk). b. This image shows pleural effusion accompanying bronchogenic cyst (Asterisk). Such effusions may occur due to atelectasis and disruption of lymphatic drainage, or they may be indicative of perforation in the cyst. In this case, perforation was detected intraoperatively. $\mathrm{c}$ and $2 \mathrm{~d}$ indicate preoperative and postoperative chest radiograms. 

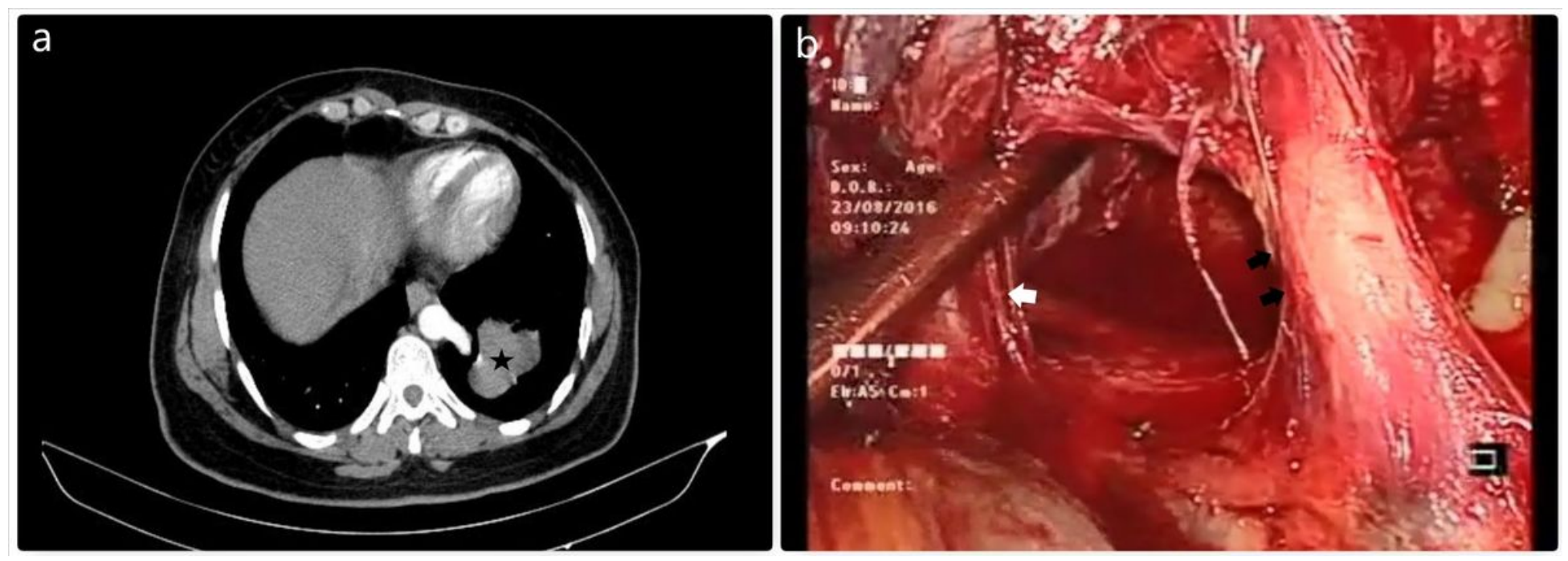

\section{Figure 3}

Extralobar sequestration (Asterisk) was seen in the left lower lobe, and the arterial supply of the pulmonary sequestration was detected preoperatively via the thorax CT (Figure 3a). VATS resection was performed. Arterial blood supply (Black arrows) from the aorta was seen intraoperatively and dissected with an endoscopic vascular stapler (Figure 3b). The white arrow indicates the pulmonary vein.
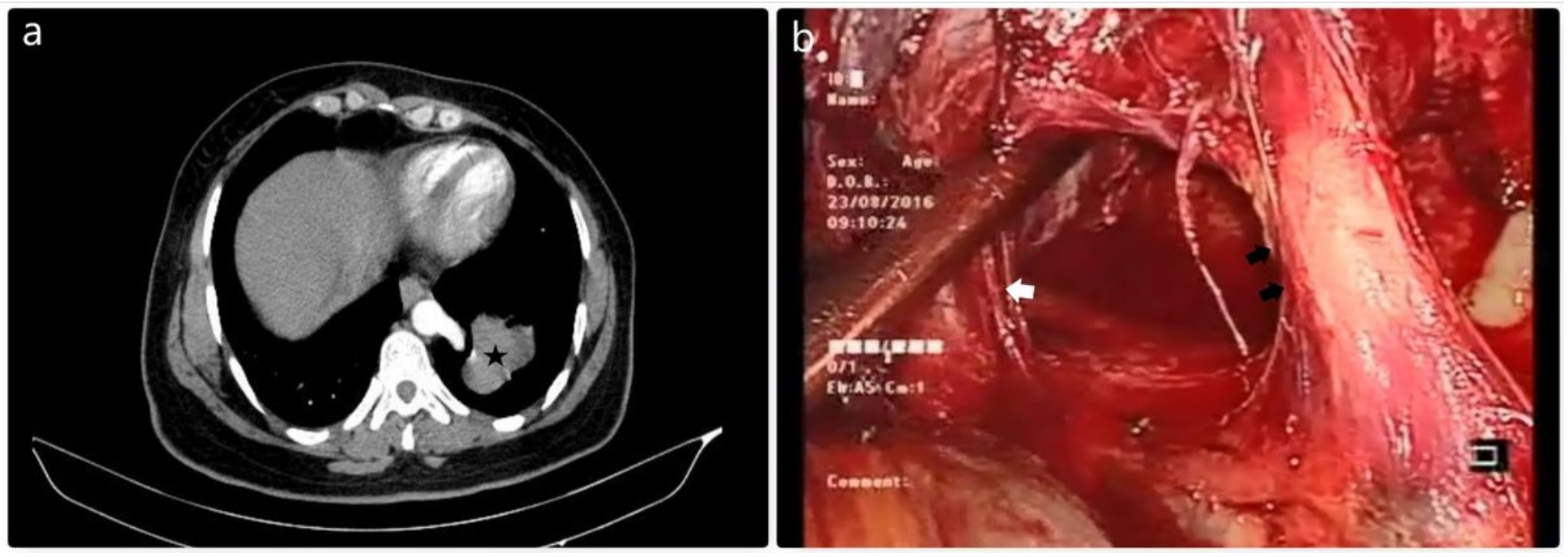

\section{Figure 3}

Extralobar sequestration (Asterisk) was seen in the left lower lobe, and the arterial supply of the pulmonary sequestration was detected preoperatively via the thorax CT (Figure 3a). VATS resection was performed. Arterial blood supply (Black arrows) from the aorta was seen intraoperatively and dissected with an endoscopic vascular stapler (Figure 3b). The white arrow indicates the pulmonary vein. 

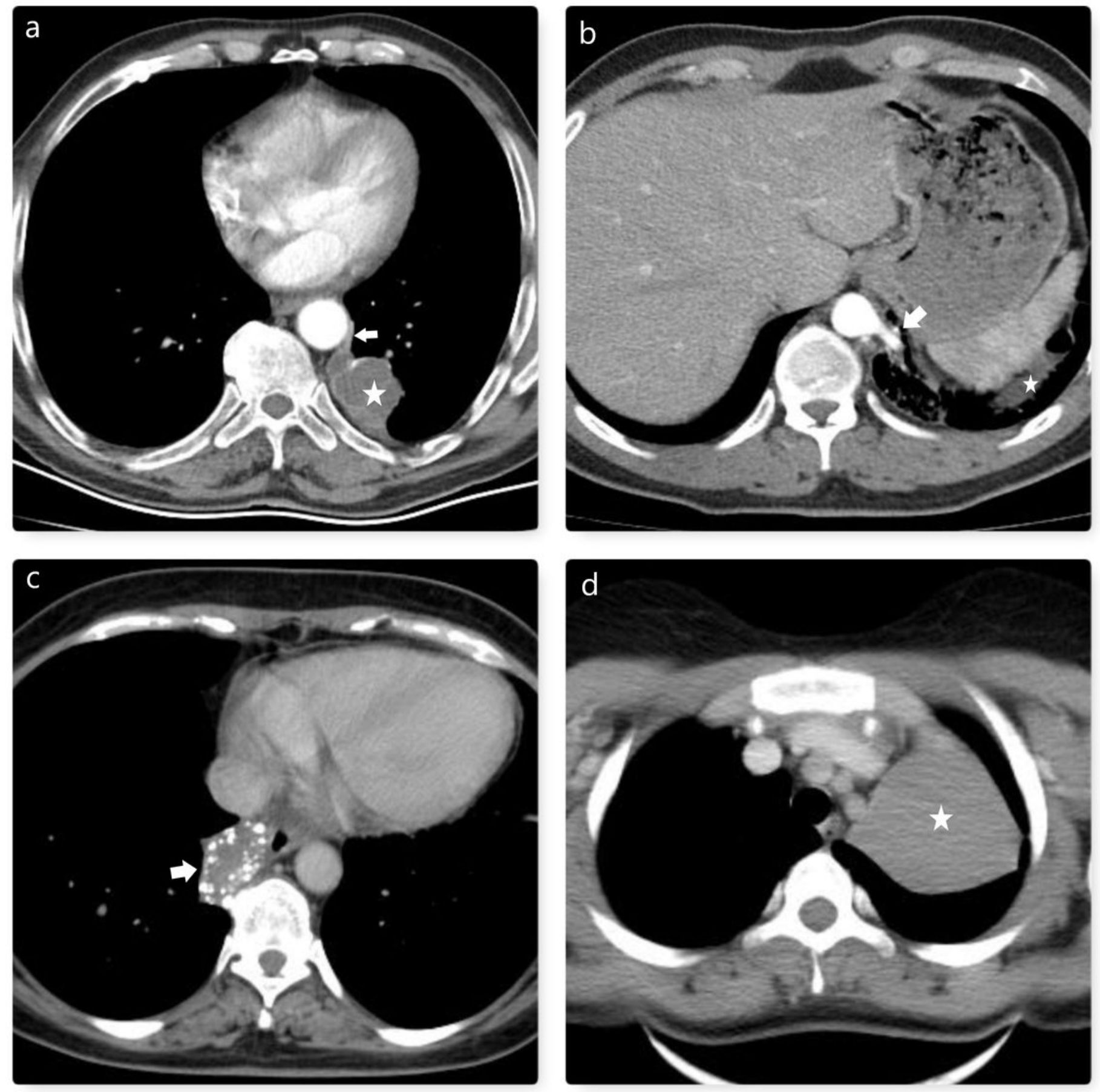

Figure 4

a and $4 \mathrm{~b}$ show left-sided intralobar sequestrations (Asterisks). Arrows indicate aortic branches. c. Arrow indicates right-sided extralobar sequestration. Rarely, these lesions may contain extensive calcifications. d. The asterisk indicates left-sided extralobar sequestration. 

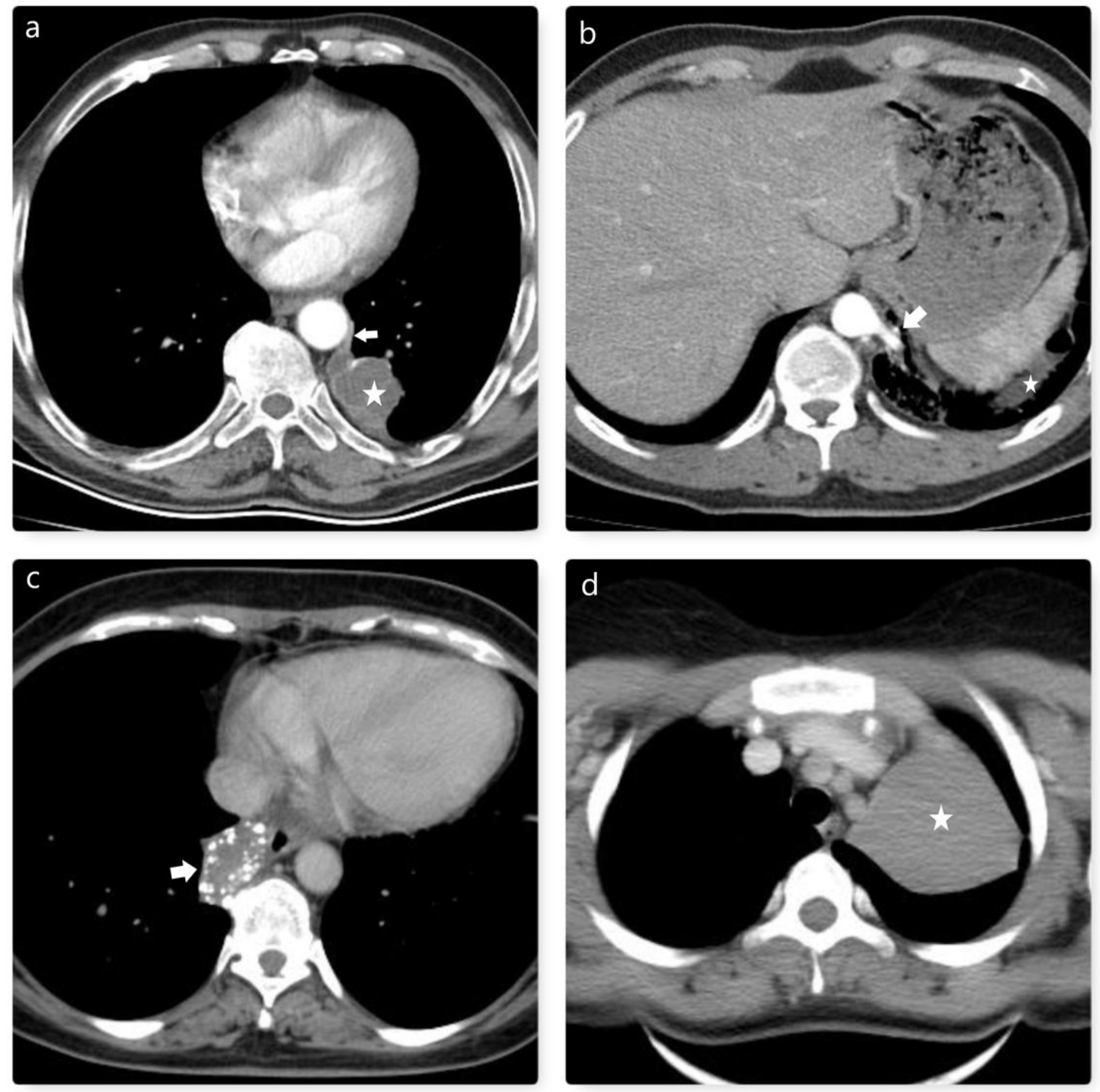

Figure 4

a and $4 \mathrm{~b}$ show left-sided intralobar sequestrations (Asterisks). Arrows indicate aortic branches. c. Arrow indicates right-sided extralobar sequestration. Rarely, these lesions may contain extensive calcifications. d. The asterisk indicates left-sided extralobar sequestration. 

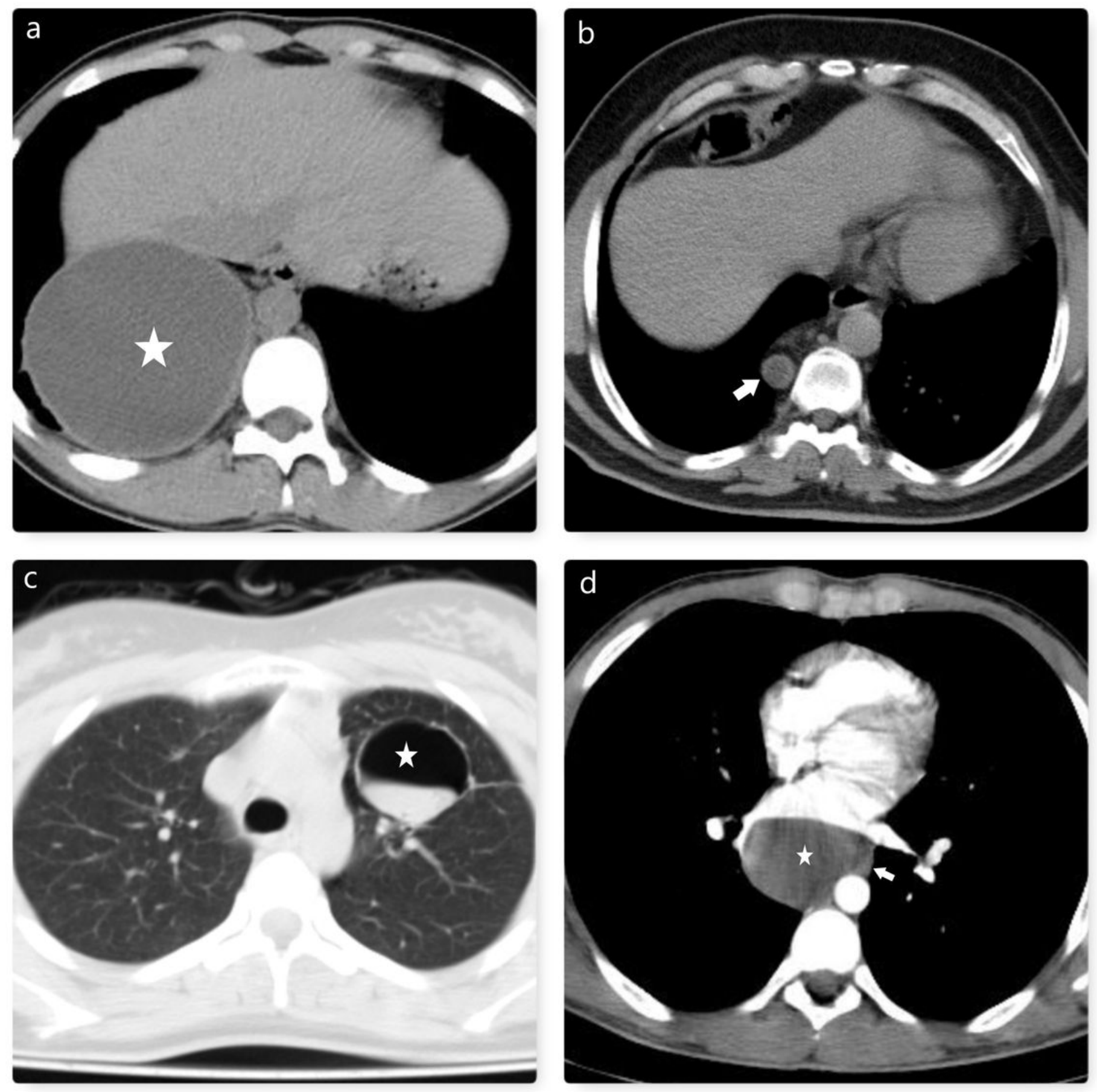

\section{Figure 5}

a. Chest CT indicates the right-sided giant enteric cyst (Asterisk). In this case, we preferred open surgery to performed complete resection. b. A much smaller enteric cyst is observed than in the previous case (Arrow). Therefore, we have preferred VATS for the excision of this cystic lesion. c. Thorax CT image of the left-sided congenital cystic adenomatoid malformation is seen (Asterisk). The left upper lobectomy was performed. $\mathrm{d}$. This thorax CT belongs to the patient with an esophagus duplication cyst (Asterisk). Arrow indicates the wall of the esophagus. There is no contraindication, but these areas of the 
mediastinum are challenging localizations for the VATS procedure. Thus, we preferred open surgery in this case.
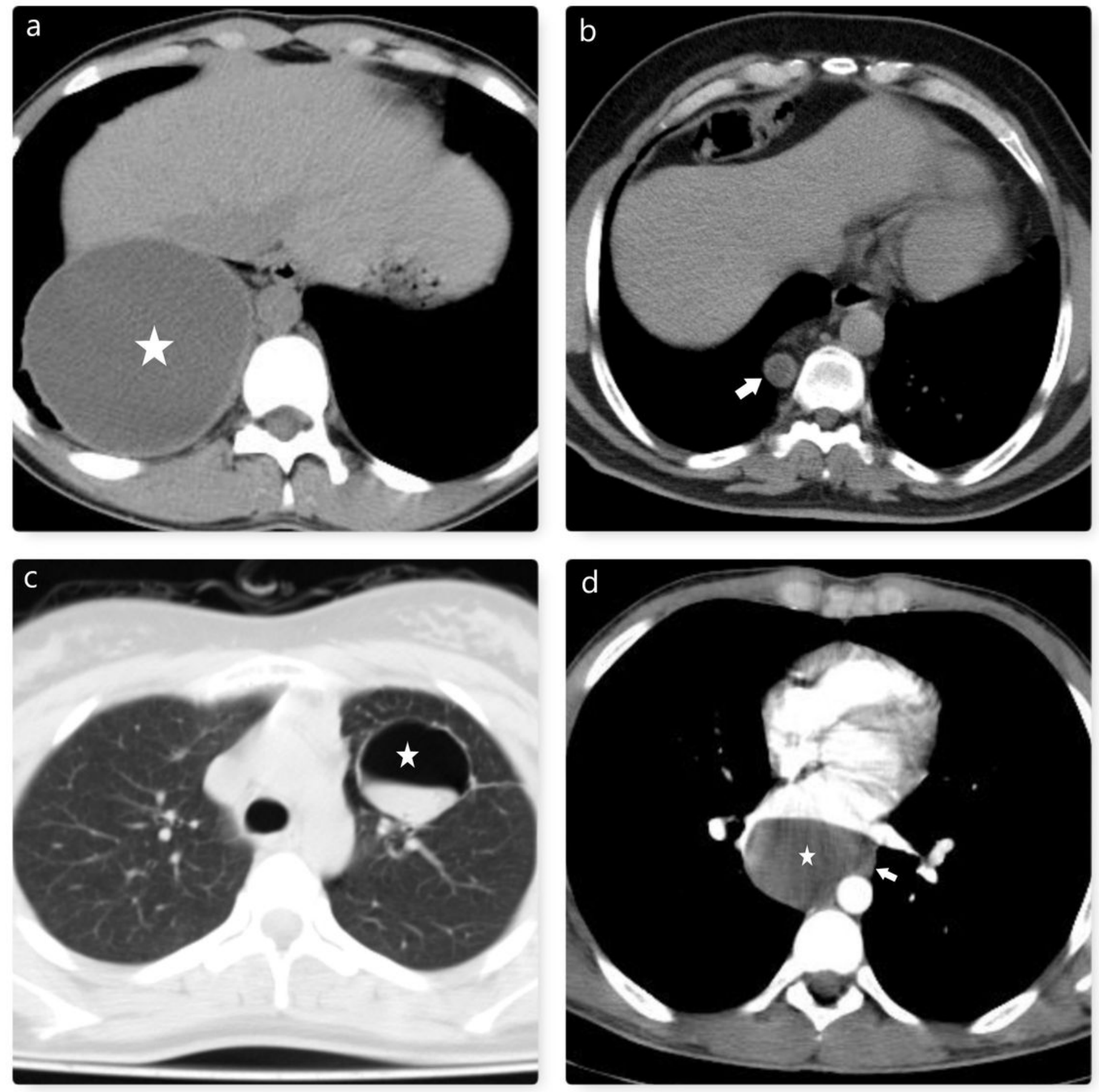

\section{Figure 5}

a. Chest CT indicates the right-sided giant enteric cyst (Asterisk). In this case, we preferred open surgery to performed complete resection. b. A much smaller enteric cyst is observed than in the previous case (Arrow). Therefore, we have preferred VATS for the excision of this cystic lesion. c. Thorax CT image of the left-sided congenital cystic adenomatoid malformation is seen (Asterisk). The left upper lobectomy 
was performed. $\mathrm{d}$. This thorax CT belongs to the patient with an esophagus duplication cyst (Asterisk). Arrow indicates the wall of the esophagus. There is no contraindication, but these areas of the mediastinum are challenging localizations for the VATS procedure. Thus, we preferred open surgery in this case. 